REVIEW ARTICLE

\title{
初回治療におけるアファチニブの有用性
}

\author{
岩間映二 $1,2 \cdot$ 岡本 勇 2
}

\section{Clinical Benefits Associated with First Line Treatment Using Afatinib}

Eiji Iwama1,2; Isamu Okamoto2

${ }^{1}$ Department of Comprehensive Clinical Oncology, Faculty of Medical Sciences, Kyushu University, Japan; ${ }^{2}$ Research Institute for Diseases of the Chest, Graduate School of Medical Sciences, Kyushu University, Japan.

ABSTRACT - Three types of EGFR-TKIs (epidermal growth factor receptor-tyrosine kinase inhibitors) such as gefitinib, erlotinib and afatinib are available for the treatment of EGFR mutation-positive lung cancer patients in Japan. Afatinib is an irreversible HER family (EGFR, HER2, HER4) blocker. Although treatment with this drug has a substantial clinical benefit, the frequency of adverse effects (AEs) such as rash, paronychia and diarrhea is high and management of these AEs is important. Two phase III studies (LUX-Lung 3, LUX-Lung 6) were performed to compare the efficacy of afatinib and platinum-based chemotherapy in previously untreated lung adenocarcinoma patients with EGFR mutations. Afatinib showed a significantly longer progression free survival (PFS) (primary endpoint) than chemotherapy in these two studies, and the results were similar to those of other clinical studies with first generation EGFR-TKIs (gefitinib, erlotinib). Afatinib also demonstrated a benefit in the overall survival (OS) for exon 19 deletion mutation-positive patients, which was not observed in other studies with first generation EGFR-TKIs. Although the mutation of threonine-790 to methionine (T790M) in EGFR has been reported to be a major cause of resistance to first generation EGFR-TKIs, the resistance mechanism to afatinib has not yet been elucidated. It is important to investigate the mechanisms of resistance to afatinib and to develop new strategies to overcome this problem. We herein summarize the utility of first line treatment with afatinib, while referring the results of both clinical studies and molecular biological studies.

(JJLC. 2015;55:866-870)

KEY WORDS — Afatinib, EGFR, Exon 19 deletion, L858R, Digital PCR

要旨一一本邦においては EGFR 遺伝子変異陽性肺癌に 対してゲフィチニブ，エルロチニブ，アファチニブの 3 剤の EGFR-TKIs の使用が可能である.アファチニブは HER ファミリー（EGFR, HER2, HER4)への不可逆的 な結合を特徵とし，良好な抗腫瘍効果が得られるが，皮 疹，爪囲炎，下痢といった副作用の頻度が高く，毒性管 理が重要となる．未治療 EGFR 遺伝子変異陽性肺癌症例 を対象としたアファチニブとプラチナ併用化学療法の効 果を比較する第 III 相臨床試験が 2 つ行われ (LUX-Lung 3, LUX-Lung 6), 両試験において, アファチニブ群の無 増悪生存期間における優越性が確認された。この点は第 一世代 EGFR-TKIs（ゲフィチニブ，エルロチニブ）と同
様であるが, エクソン 19 欠失変異症例においてプラチナ 併用化学療法と比して有意な生存期間延長効果を認めて おり，この点は第一世代 EGFR-TKIs とは一線を画する ところである。第一世代 EGFR-TKIs における獲得耐性 機序は T790M の発現が主であることが報告されている が, アファチニブについては明らかにされておらず今後 の検討を要する.これまでの臨床試験や分子生物学的研 究の結果を踏まえ, 初回治療におけるアファチニブの有 用性について概説を行う

索引用語——アファチニブ, EGFR, エクソン 19 欠失変 異, L858R, Digital PCR
1九州大学大学院医学研究院九州連携臨床腫瘍学講座 ; 2 九州大 学病院呼吸器科.
※第 55 回日本肺癌学会学術集会シンポジウム 1 「EGFR-TKI 治 療成績のさらなる改善をめざして」. 


\section{はじめに}

Epidermal growth factor receptor (EGFR) 遺伝子変異陽性 肺癌に対し, EGFR チロシンキナーゼ阻害剤（EGFRTKIs）は高い抗腫瘍効果を示し，この患者群における重 要な治療選択肢となっている.1-7 本邦では第一世代 EGFR-TKIs（ゲフィチニブ，エルロチニブ）に加えて, 第二世代 EGFR-TKI のアファチニブが承認され， 3 郕の EGFR-TKIs が使用可能となっている．各薬剤の臨床試 験の結果や分子生物学的な理解を深め, これらの EGFRTKIs をどのように使い分けるかが, 今後の日常臨床に おいて重要と考えられる.

\section{一次治療におけるアファチニブの効果}

EGFR 遺伝子変異陽性肺腺癌に対する一次治療におい て，アファチニブとプラチナ併用化学療法群を比較した 2 つの第 III 相試験の結果が報告された. 6.7 LUX-Lung 3 （LL3）試験においてはシスプラチンとペメトレキセド (CDDP + PEM), LUX-Lung 6（LL6）試験においてはシ スプラチン＋ゲムシタビン (CDDP + GEM ) との比較が 行われた。主要評価項目である無増悪生存期間 (PFS) で は, 両試験において化学療法群に対するアファチニブ群 の有意な延長効果を認め（LL3 試験：ハザード比 [HR] 0.58, 95\%CI : 0.43〜0.78, P<0.001, およびLL6 試験 : HR 0.28, 95\%CI : 0.20〜0.39, P<0.0001), ゲフィチニブ やエルロチニブと並び, アファチニブは EGFR 遺伝子変 異陽性非小細胞肺癌に対する標準治療の 1 つとなった (Table 1).

副次評価項目である全生存期間（OS）に関しては， 2 つの common mutationsであるエクソン 19 欠失変異 （Del 19）とエクソン 21 点変異（L858R）を有する患者に おいて, 化学療法群に対するアファチニブ群の良好な傾 向が示されたものの有意差には至らなかった（LL3 試 験：HR 0.78, 95\%CI : 0.58〜 1.06, P=0.11，およびLL6 試験：HR 0.83, 95\%CI：0.62〜1.09, P=0.18). しかし, Del 19 を有する症例に限ると, LL3, LL6 の両試験におい てアファチニブ群の化学療法群に対する有意かつ HR : 約 0.6 という非常に大きな差をもって, OS の延長効果が 示された (LL3 試験：HR 0.54, 95\%CI：0.36〜0.79, P= 0.0015, および LL6 試験：HR 0.64, 95\%CI：0.44〜0.94, $P=0.023)$ (Table 1). ${ }^{8}$

第一世代 EGFR-TKIs と化学療法を比較した第 III 相 試験では, OSにおいて差は認められていないが,これは 化学療法群において後治療として第一世代 EGFR-TKIs へのクロスオーバーが行われていたためと考えられる. 一方, LL3 およびLL6 試験では, 化学療法群の後治療と しての EGFR-TKIs は第一世代 EGFR-TKIs が投与され
ており，アファチニブの投与は行われていない。本邦の ように第一世代 EGFR-TKIs の保険償還が認められてい る国においては, 化学療法群の後治療として第一世代 EGFR-TKIs の投与が $90 \%$ 以上で行われているが, これ らの国においても Del 19 陽性症例におけるアファチニ ブ群の化学療法群に対する OS 延長効果は, HR : 0.50 を下回る非常に大きな差をもって得られている。これら の結果は, Del 19 陽性症例に対するアファチニブと第一 世代 EGFR-TKIs の効果の差異が Del 19 陽性症例に対 するアファチニブ群の OS 延長効果に寄与したことを示 唆するものである.

EGFR 遺伝子変異陽性肺癌症例に対する初回治療とし てのアファチニブと第一世代 EGFR-TKIs を直接比較し た臨床試験の結果は報告されていないが, LL3 試験と LL6 試験で示された Del 19 陽性症例に対する OS 延長 効果は特筆すべき点であり, Del 19 陽性症例に対する一 次治療としてアファチニブの使用を積極的に検討すべき と考えられる.

\section{Del 19 と L858R の分子生物学的特徵}

EGFR は細胞膜貫通型の受容体であり, 細胞外領域に 増殖因子（リガンド）が結合すると構造が変化して二量 体（ホモダイマーやへテロダイマー）を形成, 細胞内領 域のチロシンキナーゼが ATPを利用して互いのチロシ ン残基をリン酸化し, 生存, 増殖, 転移, 血管新生など の癌細胞にとって重要なシグナルを伝えていく． Del 19 や L858R のようにEGFRのキナーゼドメインに遺伝子 変異が起こると構造変化と二量体形成が容易に起こり, EGFR が活性化状態に保たれることで恒常的にリン酸化 シグナルを下流に伝えると考えられている. 9,10

基礎実験において, Del 19 陽性 EGFRによる下流への リン酸化シグナルは EGFR-TKI の濃度依存的に抑制さ れるものの，L858R 陽性に関しては濃度依存的な抑制が 得られにくいという報告を認める.11また, Del 19 と L858R では二量体形成後の自己リン酸化部位が異なり, それに続く下流へのシグナル伝達が異なるという報告 や, 12 L858R 陽性の EGFR は二量体を形成しないと活性 化しないが, Del 19 陽性の EGFR は単体の状態でも下流 シグナルが活性化されるという報告も認める.13このよ うに分子生物学的にも Del 19 と L $858 \mathrm{R}$ の違いが報告さ れており，EGFR-TKIに対する効果にも影響している可 能性が示唆される。

\section{EGFR-TKIs 3 剤の特徵}

ErbBファミリーはErbB1（HER1，EGFR), ErbB2 (HER2), ErbB3 (HER3), ErbB4 (HER4) の 4 つが存 在する.ゲフィチニブとエルロチニブは EGFR (ErbB1) 
Table 1. Summary of the Randomized Phase III Trials Comparing the Efficacy of EGFR-TKIs and Chemotherapy

\begin{tabular}{|c|c|c|c|c|c|c|c|c|c|c|c|c|}
\hline \multirow{3}{*}{$\begin{array}{c}\text { EGFR- } \\
\text { TKI } \\
\text { Study } \\
\begin{array}{l}\text { Treat- } \\
\text { ment }\end{array}\end{array}$} & \multicolumn{4}{|c|}{ Afatinib } & \multicolumn{4}{|c|}{ Gefitinib } & \multicolumn{4}{|c|}{ Erlotinib } \\
\hline & \multicolumn{2}{|c|}{ LUX-Lung 3} & \multicolumn{2}{|c|}{ LUX-Lung 6} & \multicolumn{2}{|c|}{ WJTOG3405 } & \multicolumn{2}{|c|}{ NEJ002 } & \multicolumn{2}{|c|}{ EURTAC } & \multicolumn{2}{|c|}{ OPTIMAL } \\
\hline & Afatinib & $\begin{array}{l}\text { CDDP/ } \\
\text { PEM }\end{array}$ & Afatinib & $\begin{array}{c}\text { CDDP/ } \\
\text { GEM }\end{array}$ & Gefitinib & $\begin{array}{l}\text { CDDP/ } \\
\text { DTX }\end{array}$ & Gefitinib & $\begin{array}{l}\text { CBDCA/ } \\
\text { PTX }\end{array}$ & Erlotinib & $\begin{array}{l}\text { Chemo- } \\
\text { therapy }\end{array}$ & Erlotinib & $\begin{array}{c}\text { CBDCA/ } \\
\text { GEM }\end{array}$ \\
\hline \multirow{2}{*}{$\begin{array}{c}\text { PFS } \\
\text { (month) }\end{array}$} & 11.1 & 6.9 & 11 & 5.6 & 9.2 & 6.3 & 10.8 & 5.4 & 9.7 & 5.2 & 13.1 & 4.6 \\
\hline & \multicolumn{2}{|c|}{$\begin{array}{l}\text { HR: } 0.58 \\
P<0.001\end{array}$} & \multicolumn{2}{|c|}{$\begin{array}{c}\text { HR: } 0.28 \\
P<0.0001\end{array}$} & \multicolumn{2}{|c|}{$\begin{array}{c}\text { HR: } 0.49 \\
P<0.0001\end{array}$} & \multicolumn{2}{|c|}{$\begin{array}{l}\text { HR: } 0.30 \\
P<0.001\end{array}$} & \multicolumn{2}{|c|}{$\begin{array}{c}\text { HR: } 0.37 \\
P<0.0001\end{array}$} & \multicolumn{2}{|c|}{$\begin{array}{c}\text { HR: } 0.16 \\
P<0.0001\end{array}$} \\
\hline OS & 31.6 & 28.2 & 23.6 & 23.5 & 34.8 & 37.3 & $27.7^{*}$ & $26.6^{*}$ & 19.3 & 19.5 & 22.7 & 28.9 \\
\hline $\begin{array}{c}\text { common } \\
\text { mutation } \\
\text { (month) }\end{array}$ & \multicolumn{2}{|c|}{$\begin{array}{c}\text { HR: } 0.78 \\
P=0.11\end{array}$} & \multicolumn{2}{|c|}{$\begin{array}{c}\text { HR: } 0.83 \\
P=0.18\end{array}$} & \multicolumn{2}{|c|}{$\begin{array}{c}\text { HR: } 1.25 \\
P=0.21\end{array}$} & \multicolumn{2}{|c|}{$\begin{array}{c}\text { HR: } 0.89 \\
P=0.48\end{array}$} & \multicolumn{2}{|c|}{$\begin{array}{c}\text { HR: } 1.04 \\
P=0.87\end{array}$} & \multicolumn{2}{|c|}{$\begin{array}{c}\text { HR: } 1.04 \\
P=0.69\end{array}$} \\
\hline $\begin{array}{c}\text { OS } \\
\text { Del } 19 \\
\text { (month) }\end{array}$ & \multicolumn{2}{|c|}{$\begin{array}{c}\text { HR: } 0.54 \\
P=0.0015\end{array}$} & \multicolumn{2}{|c|}{$\begin{array}{l}\text { HR: } 0.64 \\
P=0.023\end{array}$} & & & & & & & & \\
\hline $\begin{array}{c}\text { OS } \\
\text { L858R } \\
\text { (month) }\end{array}$ & $\begin{array}{l}27.6 \\
\text { HR: } \\
P=\end{array}$ & $\begin{array}{l}\quad 40.3 \\
1.30 \\
.29\end{array}$ & $\begin{array}{l}19.6 \\
\text { HR: } \\
P=\end{array}$ & $\begin{array}{l}\quad 24.3 \\
1.22 \\
0.34\end{array}$ & & & & & & & & \\
\hline
\end{tabular}

Sequist LV, et al. J Clin Oncol 2013, Wu YL, et al. Lancet Oncol 2014, Maemondo M, et al. N Engl J Med 2010, Mitsudomi T, et al. Lancet Oncol 2010, Yoshioka H, et al. ASCO2014, Inoue A, et al. Ann Oncol 2013, Rosell R, et al. Lancet Oncol 2012, Zhou C, et al. Lancet Oncol 2011, Zhou C, et al. ASCO2012. *OS including the patients with minor mutations.

に可逆的に結合して作用する第一世代の EGFR-TKIs で あり,アファチニブは EGFR を含む ErbB ファミリー (ErbB1，ErbB2，ErbB4）に不可逆的に結合して作用す る第二世代の EGFR-TKI である.

ゲフィチニブの承認用量は $250 \mathrm{mg}$ であり最大耐用量 (700 mg)の約 1/3 であるが, エルロチニブの承認用量は 最大耐用量と同じ $150 \mathrm{mg}$ である. また, 承認用量(通常 使用量）のエルロチニブ $150 \mathrm{mg} /$ 日と同等の AUCをゲ フィチニブで得るには, 承認用量（通常使用量）の約 3 倍の $700 \mathrm{mg} /$ 日の投与が必要であると考えられてい

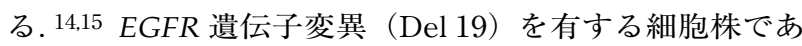
る PC-9 に対するゲフィチニブ，エルロチニブの IC50 は ほぼ等しいことを考慮すると, エルロチニブはゲフィチ ニブと比較し, 癌細胞に対してょり十分な血中濃度で使 用できることを示している. 16,17 一方, アファチニブは 第一世代 EGFR-TKIs と比較して EGFRに対する親和 性が高く，低濃度での阻害活性を有すること（PC-9 に対 する IC50 は約 $1 / 50$ ), 通常使用量の $40 \mathrm{mg}$ /日（承認用量 は最大耐容量と同じ $50 \mathrm{mg}$ ) で十分な血中濃度が得られ ることが報告されている. ${ }^{18,19}$ ゲフィチニブは $250 \mathrm{mg}$ の 1 凨型であるのが, エルロチニブは $25 \mathrm{mg}, 100 \mathrm{mg}$, $150 \mathrm{mg}$ の 3 用型, アファチニブは $20 \mathrm{mg}, 30 \mathrm{mg}, 40 \mathrm{mg}$, $50 \mathrm{mg}$ の 4 片型が利用可能であり, エルロチニブやア ファチニブにおいては高い血中濃度での使用と, 副作用 などに応じた用量調整が可能となっている.

ゲフィチニブとエルロチニブは EGFRに結合するこ とから, 理論的には EGFR+EGFRのホモダイマー,

$\mathrm{EGFR}+\mathrm{ErbB} 2, \mathrm{EGFR}+\mathrm{ErbB} 3, \mathrm{EGFR}+\mathrm{ErbB} 4$ のヘテ
ロダイマーの機能を阻害することが考えられる. 一方, アファチニブは EGFR だけでなく ErbB2, ErbB4にも結 合可能であることから, 理論的には, 上記に加えて ErbB2 + ErbB2, ErbB4+ErbB4のホモダイマー, ErbB2 + ErbB3, ErbB2+ ErbB4, ErbB3+ ErbB4のへ テロダイマーによるシグナル伝達を阻害することが可能 であり, 多様なダイマー形成に対する効果がアファチニ ブの有効性に関与している可能性も考えられる.

\section{アファチニブによる有害事象}

$$
\text { アファチニブはゲフィチニブ, エルロチニブに比べ, }
$$
皮疹や爪囲炎，下痢の頻度が多いことが報告されてお り, 67 日本人における Grade 3 以上の頻度も皮疹 $20.4 \%$, 爪囲炎 $24.1 \%$, 下痢 $20.4 \%$ と高いことが報告され ている(LL3 試験における成績)。これによって減量を必 要とした症例の割合は $75 \%$ であり, 第一世代の EGFRTKIs を使用した場合に報告されている割合（40～50\%） と比較すると，アファチニブを用いた場合の減量の割合 は高い. しかしながら中止に至った症例の割合は $14.8 \%$ と他の EGFR-TKIs と比較して特別高いものではない. これは, 適切に副作用に対応し, 減量を行えば, 中止す ることなくアファチニブの継続が可能であることを示し ている.

\section{EGFR-TKIs 耐性機序の解明}

第一世代 EGFR-TKIs に対して獲得耐性を呈する症例 の約 $60 \%$ に, T790M の発現が見られることが報告され ている. ${ }^{20,21}$ 一方, 高感度の検出系を用いれば EGFR- 


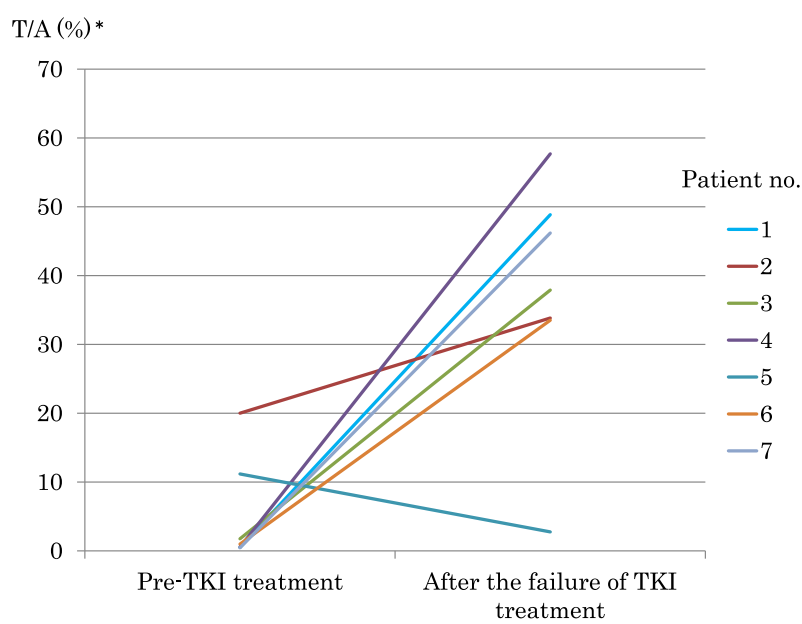

Figure 1. Quantitative change of $T 790 \mathrm{M}$ in the seven evaluated patients. *The ratio of the number of T790M alleles to that of the activating mutation alleles.

TKIs 投与前から T790M の発現を確認可能であるとす る報告もある. ${ }^{22,23}$ Digital PCR (dPCR) は, DNA 抽出液 を細分化し，ターゲット遺伝子変異陽性アレルが1つず つ個々の反応系に入るようにセッティングし，個々の反 応系の中でターゲット遺伝子変異陽性アレルを検出する 測定系である。これにより，ターゲット遺伝子変異陽性 アレルの検出を高感度かつ定量的に行うことが可能とな る.

我々は，第一世代 EGFR-TKIs を使用した EGFR 遺伝 子変異を有する肺腺癌患者 19 例から得られた 25 腫瘍検 体 (EGFR-TKI 投与前 13 検体, EGFR-TKI 投与後（耐性

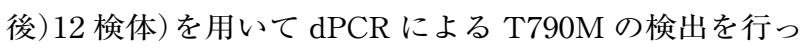
たところ，EGFR-TKIs 投与前に得られた検体の全例で T790M が検出された.これらの症例においては投与前に T790M が確認されているにも関わらず, EGFR-TKIに よる良好な抗腫瘍効果が得られていた. 24 このことは T790M を高感度に検出するだけでなく, どの程度発現し ているかを評価すること（定量的な検出）が， T790M が耐性に寄与しているかどうかを検討する上で重要であ ると考えられる。そこで我々は, $\mathrm{dPCR}$ の特徵を生かし, T790M 陽性アレルが検体中に何個存在しているかを測 定するとともに，活性型遺伝子変異 (Del 19, L858R) に ついても同様に測定し, T790M に対する活性型遺伝子変 異 (activating mutations) の割合（ $\mathrm{T} / \mathrm{A}$ 比）を求めた. その結果, 投与前と獲得耐性後の両方の検体が得られた 7 症例中 6 症例に打いて $\mathrm{T} / \mathrm{A}$ 比の著明な上昇を認めて おり，これらの症例においては T790M がEGFR-TKI 耐性に大きく関与していると考えられた（Figure 1).

一方，アファチニブに対する耐性機序については明ら かにされて扔らず，耐性機序の解明は耐性克服を含む今
後の治療戦略を考える上で重要な課題である. 癌患者の 血液中には腫瘍由来の循環遊離 DNA (circulating free DNA, cfDNA) や循環腫瘍細胞 (circulating tumor cells, CTC) が認められている. 近年, これらを検出し, 遺伝 子解析を行うことで臨床応用に繋げようとする研究が, 種々の癌領域に扔いて試みられている. 25,26 我々は, ア ファチニブに対する耐性機序の探索と cfDNA の有用性 を検討するための多施設共同前向きバイオマーカー研究 を実施中である（UMIN000013806）。本研究では EGFRTKI 未治療, EGFR 遺伝子変異陽性の進行肺腺癌症例に 対して増悪または許容できない毒性が認められるまでア ファチニブを投与し，腫瘍検体の採取をアファチニブ投 与前, 増悪後に施行, 血漿検体の採取を投与前, 投与 4 週， 24 週後，増悪後に施行する. 腫瘍検体からの DNA と血漿検体からの cfDNA に対して Scorpion-ARMS (ARMS), dPCR, 次世代シークエンスを用いて腫瘍の生 存, 増殖に関わる遺伝子変異の解析を行い, アファチニ ブ耐性機序の探索を行う. 本研究は 2014 年 5 月から登録 を開始し, 同年 11 月までに予定症例数 (30 例) の登録を 完了, 現在解析中である.

\section{まとめ}

アファチニブは懸念される毒性に関しても減量を含め た適切な対応，対策を講じれば良好にコントロール可能 であり，LL3 試験，LL6 試験で示された Del 19 陽性症例 に対する効果を考えると, Del 19 陽性の EGFR 遺伝子変 異陽性肺癌症例に対してはアファチニブを一次治療から 積極的に使用すべきであると考えられる. アファチニブ に対する耐性機序の解明を行うことが，耐性克服を含め た今後の治療戦略を開発する上で重要である.

本論文内容に関連する著者の利益相反：岡本 勇 [講演料な ど] 中外製薬（株），ファイザー(株)，日本イーライリリー (株), 大鵬薬品工業 (株) [委受託研究 (治駼等) ] アストラゼ 衤力（株）

\section{REFERENCES}

1. Mok TS, Wu YL, Thongprasert S, Yang CH, Chu DT, Saijo N, et al. Gefitinib or carboplatin-paclitaxel in pulmonary adenocarcinoma. N Engl J Med. 2009;361:947-957.

2. Maemondo M, Inoue A, Kobayashi K, Sugawara S, Oizumi S, Isobe H, et al. Gefitinib or chemotherapy for non-small-cell lung cancer with mutated EGFR. $N$ Engl $J$ Med. 2010;362:2380-2388.

3. Mitsudomi T, Morita S, Yatabe Y, Negoro S, Okamoto I, Tsurutani J, et al. Gefitinib versus cisplatin plus docetaxel in patients with non-small-cell lung cancer harbouring mutations of the epidermal growth factor receptor (WJTOG3405): an open label, randomised phase 3 
trial. Lancet Oncol. 2010;11:121-128.

4. Rosell R, Carcereny E, Gervais R, Vergnenegre A, Massuti B, Felip E, et al. Erlotinib versus standard chemotherapy as first-line treatment for European patients with advanced EGFR mutation-positive non-small-cell lung cancer (EURTAC): a multicentre, open-label, randomised phase 3 trial. Lancet Oncol. 2012;13:239-246.

5. Zhou C, Wu YL, Chen G, Feng J, Liu XQ, Wang C, et al. Erlotinib versus chemotherapy as first-line treatment for patients with advanced EGFR mutation-positive nonsmall-cell lung cancer (OPTIMAL, CTONG-0802): a multicentre, open-label, randomised, phase 3 study. Lancet Oncol. 2011;12:735-742.

6. Sequist LV, Yang JC, Yamamoto N, O'Byrne K, Hirsh V, Mok T, et al. Phase III study of afatinib or cisplatin plus pemetrexed in patients with metastatic lung adenocarcinoma with EGFR mutations. J Clin Oncol. 2013;31:33273334.

7. Wu YL, Zhou C, Hu CP, Feng J, Lu S, Huang Y, et al. Afatinib versus cisplatin plus gemcitabine for first-line treatment of Asian patients with advanced non-smallcell lung cancer harbouring EGFR mutations (LUX-Lung 6): an open-label, randomised phase 3 trial. Lancet Oncol. 2014;15:213-222.

8. Yang JC, Wu YL, Schuler M, Sebastian M, Popat S, Yamamoto N, et al. Afatinib versus cisplatin-based chemotherapy for EGFR mutation-positive lung adenocarcinoma (LUX-Lung 3 and LUX-Lung 6): analysis of overall survival data from two randomised, phase 3 trials. Lancet Oncol. 2015;16:141-151.

9. Lynch TJ, Bell DW, Sordella R, Gurubhagavatula S, Okimoto RA, Brannigan BW, et al. Activating mutations in the epidermal growth factor receptor underlying responsiveness of non-small-cell lung cancer to gefitinib. $N$ Engl J Med. 2004;350:2129-2139.

10. Sordella R, Bell DW, Haber DA, Settleman J. Gefitinibsensitizing EGFR mutations in lung cancer activate antiapoptotic pathways. Science. 2004;305:1163-1167.

11. Zhu JQ, Zhong WZ, Zhang GC, Li R, Zhang XC, Guo AL et al. Better survival with EGFR exon 19 than exon 21 mutations in gefitinib-treated non-small cell lung cancer patients is due to differential inhibition of downstream signals. Cancer Lett. 2008;265:307-317.

12. Okabe T, Okamoto I, Tamura K, Terashima M, Yoshida T, Satoh T, et al. Differential constitutive activation of the epidermal growth factor receptor in non-small cell lung cancer cells bearing EGFR gene mutation and amplification. Cancer Res. 2007;67:2046-2053.

13. Cho J, Chen L, Sangji N, Okabe T, Yonesaka K, Francis $\mathrm{JM}$, et al. Cetuximab response of lung cancer-derived EGF receptor mutants is associated with asymmetric dimerization. Cancer Res. 2013;73:6770-6779.

14. Hidalgo M, Siu LL, Nemunaitis J, Rizzo J, Hammond LA, Takimoto C, et al. Phase I and pharmacologic study of OSI-774, an epidermal growth factor receptor tyrosine kinase inhibitor, in patients with advanced solid malig- nancies. J Clin Oncol. 2001;19:3267-3279.

15. Ranson M, Hammond LA, Ferry D, Kris M, Tullo A, Murray PI, et al. ZD 1839, a selective oral epidermal growth factor receptor-tyrosine kinase inhibitor, is well tolerated and active in patients with solid, malignant tumors: results of a phase I trial. J Clin Oncol. 2002;20:22402250.

16. Koizumi F, Shimoyama T, Taguchi F, Saijo N, Nishio K. Establishment of a human non-small cell lung cancer cell line resistant to gefitinib. Int J Cancer. 2005;116:36-44.

17. Chin TM, Quinlan MP, Singh A, Sequist LV, Lynch TJ, Haber DA, et al. Reduced Erlotinib sensitivity of epidermal growth factor receptor-mutant non-small cell lung cancer following cisplatin exposure: a cell culture model of second-line erlotinib treatment. Clin Cancer Res. 2008; 14:6867-6876.

18. Kim Y, Ko J, Cui Z, Abolhoda A, Ahn JS, Ou SH, et al. The EGFR T790M mutation in acquired resistance to an irreversible second-generation EGFR inhibitor. Mol Cancer Ther. 2012;11:784-791.

19. Yap TA, Vidal L, Adam J, Stephens P, Spicer J, Shaw H, et al. Phase I trial of the irreversible EGFR and HER2 kinase inhibitor BIBW 2992 in patients with advanced solid tumors. J Clin Oncol. 2010;28:3965-3972.

20. Kobayashi S, Boggon TJ, Dayaram T, Jänne PA, Kocher $\mathrm{O}$, Meyerson M, et al. EGFR mutation and resistance of non-small-cell lung cancer to gefitinib. $N$ Engl J Med. 2005; 352:786-792.

21. Yu HA, Arcila ME, Rekhtman N, Sima CS, Zakowski $\mathrm{MF}, \mathrm{Pao} \mathrm{W}$, et al. Analysis of tumor specimens at the time of acquired resistance to EGFR-TKI therapy in 155 patients with EGFR-mutant lung cancers. Clin Cancer Res. 2013;19:2240-2247.

22. Su KY, Chen HY, Li KC, Kuo ML, Yang JC, Chan WK, et al. Pretreatment epidermal growth factor receptor (EGFR) T790M mutation predicts shorter EGFR tyrosine kinase inhibitor response duration in patients with non-small-cell lung cancer. J Clin Oncol. 2012;30:433-440.

23. Fujita Y, Suda K, Kimura H, Matsumoto K, Arao T, Nagai $T$, et al. Highly sensitive detection of EGFR T790M mutation using colony hybridization predicts favorable prognosis of patients with lung cancer harboring activating EGFR mutation. $J$ Thorac Oncol. 2012;7:16401644.

24. Iwama E, Takayama K, Harada T, Okamoto I, Ookubo F, Kishimoto J, et al. Highly sensitive and quantitative evaluation of the EGFR T790M mutation by nanofluidic digital PCR. Oncotarget. 2015;6:20466-20473.

25. Maheswaran S, Sequist LV, Nagrath S, Ulkus L, Brannigan B, Collura CV, et al. Detection of mutations in EGFR in circulating lung-cancer cells. $N$ Engl J Med. 2008; 359:366-377.

26. Dawson SJ, Tsui DW, Murtaza M, Biggs H, Rueda OM, Chin SF, et al. Analysis of circulating tumor DNA to monitor metastatic breast cancer. $N$ Engl J Med. 2013;368: 1199-1209. 